\title{
Introduction \\ Genocide: definitions, questions, settler-colonies
}

\author{
Ann Curthoys and John D ocker
}

\author{
Genocide is ... a composite of different acts of persecution or destruction. \\ Raphaël Lemkin, Axis rule in occupied Europe ${ }^{1}$ \\ ... we need far more, not fewer, serious comparative studies. \\ Ward Churchill, A little matter of genocide ${ }^{2}$
}

The idea for this collection of essays on 'Genocide'? came originally from our reading of Marcia Langton's comment in A ustralian Humanities Review in mid-2000. She said that A boriginal writing, scholarship, and research are taking on the feel of Holocaust studies in the sense that Aboriginal people write, read, and research 'to try to understand the terrible, inexplicable past'. She expressed disgust at 'those who do not want what happened to us and our ancestors remembered into "history"'. She did not use the word 'genocide'.

We thought the questions she raised, of how to come to terms with terrible pasts, and to what degree one can use insights from one history to interrogate another, deserved further thought. The unresolved issue for us was whether the notion of genocide could be fairly applied to Australian history. The Human Rights Commission's Bringing Them Home report of 1997, which investigated the history and effects of A boriginal child removal in the nineteenth and twentieth centuries, had controversially argued that Australian child removal practices fell within the definition of genocide used in the UN 1948 Genocide convention. In other words, Australia had its own history of genocide. This aspect of the report horrified many Australians of quite varying political views. Many people, including historians, rejected the notion that child removal could be reasonably described as 'genocide'.

We did not know where to stand in this debate. W as the term genocide applicable to Australian history in relation to the Stolen Generations? Did it apply to other aspects of the past, such as Australia's history of massacres and violence on the frontiers of set-

Lemkin 1944: 92.

2. Churchill 1997: 75. 
tlement? Ought not Australians to be more aware of the international debates, as a way of clarifying our thinking?

We approached the editorial board of A boriginal $\mathrm{H}$ istory (of which Ann is a member) and offered to edit a collection of essays entitled "'Genocide"? Australian A boriginal History in International Perspective'. After some soul-searching, the board agreed to take up our offer. In July 2000, we approached some possible contributors, more than actually appear in this volume, and asked them to 'address Australian and/ or international debates around concepts such as genocide, Holocaust, trauma, guilt, and apology, and their applicability or otherwise in the Australian context'. We sought authors with knowledge of international debates and at the same time a desire to contribute to increased understanding of Australian A boriginal history. Our main purpose was, and remains, to see the issues canvassed in a serious and scholarly manner, and we assured the board that 'we seek neither false anal ogy on the one hand, nor the isolation of Australia from international debates on the other'.

It took a little over a year to recruit our authors, allow them appropriate writing time, and conduct a demanding refereeing and revision process. In that time, a great deal happened. While our contributors were working on their essays, the public debate over the term 'genocide' and whether and how it can be applied to Australian history greatly intensified. Some of the debate was about matters of historical interpretation the nature and extent of A boriginal child removal, and of killing on the frontiers of settlement - and much of it has been about whether 'genocide' is an appropriate or a misleading term for characterising some or all of these events. Many felt that 'genocide' properly referred only to the Holocaust, that is the killing of millions of Jews by $\mathrm{Nazi}$ Germany, and that any comparison with the Holocaust was insensitive to the latter's uniquely terrible nature as well as wildly exaggerating the negative aspects of Australia's history of colonisation, dispossession, institutionalisation, and cultural imposition.

One of the leading opponents of the use of the term 'genocide' to describe child removal as it occurred in Australia was a group associated with the journal Quadrant, which published several articles disputing the findings of the Bringing Them $\mathrm{H}$ ome report. Q uadrant sponsored a seminar on A boriginal history over the weekend of 9-10 September 2000, at which a number of speakers defended Australia's record on child removal, and opposed its characterisation as 'genocide'. A former editor of Quadrant, Robert Manne, became the foremost outspoken critic of its current position, describing as 'denialists' those who thought the Bringing Them $\mathrm{H}$ ome report misrepresented the history of child removal. In April 2001, his book In denial: the Stolen Generations and the Right appeared, generating sustained discussion. ${ }^{3}$ We have been able to include in this collection Bain Attwood's analysis of Manne's argument, and several other contributors (Tatz, Moses) also refer to it.

Just as sharp as the debate over the Stolen Generations report was a parallel debate on the extent of killing on the frontier. At the Q uadrant seminar, Keith Windschuttle launched his attack on the work of Henry Reynolds, especially the latter's estimate that approximately 20000 Aboriginal people were killed in the course of the

3. Schaffer 2001. 
European invasion and settlement of the continent. Windschuttle was not the first to suggest that reports of massacres had been greatly exaggerated. Rod Moran had written in 1994 in the West A ustralian an article claiming that the Forrest River massacre, generally thought to have occurred in the Kimberleys in 1926, never happened. This had led to subsequent debate between Moran, historian Neville Green, and others. Subsequently, both Green and Moran published books on the subject. ${ }^{4}$

When sent Moran's book, M assacre myth, to review, Windschuttle was impressed by Moran's argument, and undertook a broader detailed investigation of massacre history, especially Reynolds' claims and sources. His essay on the matter was later published in the last three issues of Q uadrant in 2000. In subsequent months, the debate between Windschuttle and Reynolds was aired in public forums from Gould's bookshop in Sydney to the Lateline program on ABC television, and in newspapers such as the Sydney M orning H erald, the A ustralian's Review of Books and the Age. They debated the existence or otherwise of particular massacres, the general conduct of warfare on the frontiers of settlement, and the role of the $\mathrm{N}$ ative Police in Queensland in perpetrating or preventing frontier violence. Several historians later joined in these debates, such as Raymond Evans and Bill Thorpe in 0 verland, and again Windschuttle replied. ${ }^{5}$ The debate continues.

The question of whether or not the term 'genocide' is appropriate in the Australian context has been for us a genuine question. In the course of editing this collection, we have learnt a great deal about the legal meaning of genocide under the $1948 \mathrm{UN}$ convention, and now recognise more clearly than we did the difference between genocide as a legal concept and 'the Holocaust' as a way of describing a particular historical event.

The question-mark remains in our title, however, not only to indicate that our contributors do not all agree with one another, but also to signal the problem that the genocide debate has al ready revealed itself to be difficult and confused, in large part because legal, academic, and popular understandings of the word differ. In popular discussions, 'genocide' is equated with mass killings of an entire people, and some of the public rejection of the term rests on this assumed meaning, a meaning also shared by some academic commentators. Inga Clendinnen stirred the debate further in May 2001 when she described the 'persistent invocation of the term "genocide"' by the authors of the Bringing Them $\mathrm{H}$ ome report as 'a moral, intellectual and (as it is turning out) a political disaster'. ${ }^{6}$ Like many others, we do not agree with Clendinnen's dismissal of the genocide question, and think it remains important if we are truly to understand Australian history in its international contexts. We agree with the philosopher Raimond Gaita who has urged us all not to rush the discussion, not to be impatient. ${ }^{7}$ It is important to be careful and precise, and to recognise the limits of our current historical knowledge and that conceptual and theoretical considerations and discussions have barely begun.

4. Green 1995; M oran c1999; N eumann 1998.

Evans and Thorpe 2001; Windschuttle 2001.

Clendinnen 2001: 26.

Gaita 2001. 
One of those who continues to pursue the issue is Henry Reynolds. Just as the last of the revised articles arrived on our desk, his book on genocide appeared, also featuring a question mark. Reviewed by Peter Read in this volume, Reynolds's book is entitled An indelible stain? The question of genocide in Australia's history. It outlines the definition of genocide in the United Nations Genocide convention, briefly discusses the history of consideration of the term 'genocide' in the Australian context, and then examines a number of historical events in A ustralia and assesses them against the yardstick of the convention, in particular its stipulation that there be evidence of intention to commit genocide against a group or people. As he does not examine the extent of killing on the frontier, he chooses not to engage with critics like Keith Windschuttle, or the findings of most other historians on the consequences of invasion and settlement for Indigenous peoples in Australia. The events he considers in the light of intention - the smallpox epidemic of 1789, the frontier violence and institutionalisation in Tasmania, frontier violence in Queensland, and the assimilation policies of the 1950s - have all at one time or another been considered a form of genocide. In uncharacteristically and curiously indecisive mode, Reynolds feels that 'genocide' is probably not the appropriate term when discussing smallpox, Tasmania, or assimilation. In the context of a discussion of the Queensland frontier, however, he says:

The story of frontier conflict was punctuated with genocidal moments when settlers and police systematically pursued particular groups of A borigines with the intention of destroying them. Such moments occurred in a variety of circumstances ... How many genocidal moments there were must be a matter of speculation. Much detailed local research still needs to be done. ${ }^{8}$

$\mathrm{His}$ argument is close to that of Dirk Moses, one of our contributors, who argued in an essay in 2000 that the term genocide is less appropriately applied to Tasmania (where it is usually thought most relevant) than to Queensland (which has rarely been discussed in this context). ${ }^{9}$

One can only agree with Reynolds' call for further research. We would add to it a call for continued discussion of and participation in international debates, so that interpretation of the A ustralian sources is placed in a wide and illuminating historiography.

\section{II}

Such internationalising of debate in Australia and participation in international historiography are key purposes of this collection. Colin Tatz leads with a consideration of the meanings of genocide, and an overview of the Australian debates so far. Several contributors - Tony Barta, Andrew Markus, Anna Haebich, and Dirk Moses - consider the connections and differences between Australian and German history. Larissa Behrendt considers the standing of genocide as a crime within A ustralian law; Rosanne Kennedy investigates issues of historical writing, representation, and testimony, and what can be learnt from the largely A merican scholarship of trauma and memory, in relation to the Holocaust; and Deborah Bird Rose explores the idea that torture of the living may affect our understanding of genocide. Concluding the collection, Bain Att-

\footnotetext{
8. Reynolds 2001: 130.

9. Moses 2000.
} 
wood considers at some length Robert Manne's book, In denial: the Stolen Generations and the Right.

\section{III}

One way to illuminate the complex 'genocide' debate is to look more closely at the origins and historical contexts of the concept of genocide itself. The great twentieth century Polish-Jewish jurist Raphaël Lemkin (1901-59) is generally regarded as having defined the term in his 1944 A xis rule in occupied Europe: laws of occupation, analysis of government, proposals for redress. His definition became the basis of the 1948 UN convention, though that convention significantly altered his original formulations in ways our contributors discuss.

In A xis rule in occupied Europe Lemkin recalls that the advent of Hitler convinced him to propose for the Fifth International Conference for the Unification of Penal Law, held in Madrid in October of 1933 in cooperation with the Fifth Committee of the League of Nations, two new crimes in international law. These crimes, of barbarity and vandalism, could then be introduced into the penal legislation of the 37 participating countries. Barbarity was to be conceived as oppressive and destructive actions directed against individuals as members of a national, religious or racial group. Vandalism involved the malicious destruction of works of art and culture because they represent the specific creations of the genius of such groups. These new crimes were to be internationalised so that the offender could be punished wherever he was apprehended. Lemkin laments that the international treaty he had proposed 11 years earlier in Madrid had not been adopted. If it had, the procedural machinery for the extradition and punishment of war criminals by members of the United Nations and neutral countries would al ready be available, for dealing with the tragic experiences of German rule in occupied Europe. ${ }^{10}$ Lemkin notes that while many different acts of persecution or destruction were already prohibited in international law by the Hague Regulations of 1907, many others were not covered. The German practices of the current world war, he points out, have surpassed anything that could have been envisaged by the framers of the Hague Regulations. ${ }^{11}$

Against the limitations of both the Hague Regulations and his own formulations of barbarity and vandalism in Madrid in 1933, Lemkin proposed his new concept of 'genocide' - deriving the term from the Greek word gen os (tribe, race) and the Latin cide (killing, as in tyrannicide, homicide, fratricide). The new crime is to be defined as a twofold process, as Lemkin explains in ch IX 'Genocide' of A xis rule in occupied Europe.

Genocide has two phases: one, destruction of the national pattern of the oppressed group; the other, the imposition of the national pattern of the oppressor. ${ }^{12}$ Genocide meant that one national pattern was to be destroyed, to be replaced by the imposition of another. ${ }^{13}$

\footnotetext{
10. Lemkin 1944: xiii, 91-2.

11. Lemkin 1944: xiii, 90, 92-3, A ppendix pp 637-40. The Hague Regulations prescribe a Convention Respecting the Laws and Customs of War on Land.

12. Lemkin 1944: 79

13. Lemkin 1944: xi, 79-80.
} 
Genocide signified a 'coordinated plan' of different actions 'aiming at' the destruction of the essential foundations of the life of national groups, with the 'aim' of annihilating the groups themselves. ${ }^{14}$ Genocide was to be considered as manifold and wide ranging, a composite of actions rather than one single defining act or mode by which the destruction of a nation or group's foundations of life was to be secured. What are these constitutive actions?

For Lemkin, destruction of the essential foundations of the life of a group can occur in many ways. It involves considerations of the political, social, legal, intellectual, spiritual, economic, biological, physiological, religious, and moral. It involves considerations of health, food, and nourishment in relation to genocide and as part of genocide. It involves consideration of family life, care of children, and birth as well as death. It involves consideration of the honour and dignity of peoples, and the future of humanity as a world community.

In his consideration of genocide in relation to physical existence, Lemkin insists that genocide historically does not usually or necessarily involve mass killing, though it certainly can, as was occurring, he pointed out, in the present world war. When Germany occupied the various European countries, the 'plan of genocide' had to be adapted to political considerations in different countries; it could not be implemented in full force in all the conquered states, and accordingly the plan varied as to subject, modalities, and degree of intensity in each occupied country. Blood was an important criterion. A distinction was made between peoples considered related by blood to the German people, such as Dutchmen, Norwegians, Flemings, Luxemburgers, deemed worthy of being Germanised; and peoples thought unrelated by blood, such as Poles, Slovenes, Serbs, who were not. ${ }^{15}$ The latter group of peoples was in some way to be replaced.

Genocide in terms of physical existence could involve mass killings. The technique of mass killing was employed mainly against Jews, Poles, Slovenes, and Russians. 'Some groups - such as the Jews - are to be destroyed completely.' Sometimes mass killing was selective: in Poland, Bohemia-Moravia, and Slovenia it was the intellectuals who were being liquidated because they had al ways been considered the main bearers of national ideals and at the time of occupation they were especially suspected of organising resistance. ${ }^{16}$

Genocide could involvealso methods that were not immediate in their destruction of peoples or segments of peoples. It could involvea 'policy of depopulation' of peoples of so-called non-related blood while procreation by Germans in the occupied countries was promoted. The German occupier endeavoured to lower the birthrate of the undesired group while attempting to raise the birthrate of Germans and those like Dutch and Norwegians considered to be of 'related blood'. Illegitimate children born by Dutch and Norwegian women, begotten by German military men, were subsidised. In Luxembourg extramarital procreation with Germans was encouraged. In the occupied

14. Lemkin 1944: 79.

15. Lemkin 1944: xii, 77, 80-2, 89.

16. Lemkin 1944: 88-9. Cf. John Connelly, 1999. For the importance of blood criteria in European history, cf. John Docker 2001: 88, 100. 
countries, the birthrate of the undesired group was further decreased as a result of the separation of males from females by deporting the males for forced labour elsewhere. ${ }^{17}$

Genocide, then, entails the destruction of the 'biological structure' and 'corporal integrity' of a national, religious, or racial group. ${ }^{18}$

Genocide involves issues of health, food, and nourishment, such as the German policy of introducing a starvation rationing system for non-Germans. The undernourishment of parents because of discrimination in rationing brought about not only a lowering of the birthrate but a lowering of the survival capacity of children born of underfed parents. The Germans introduced what Lemkin calls racial discrimination in feeding. Rationing of food was organised according to racial principles throughout the occupied countries. In accordance with this 'program', the German population was getting $93 \%$ of its pre-war diet, while those in the occupied territories received much less, in particular the Poles and J ews. In terms of meat rations, the Germans received $100 \%$ of pre-war levels, the Poles 36 per cent, the Jews zero per cent. Such 'racial feeding', as Lemkin strikingly phrased it, affected captive populations in terms of calories and basic nutrients, as in carbohydrates, proteins, and fats. Its result was a decline in health amongst the occupied and subjugated peoples, instanced in anaemia, and an increase in the death rate. Health and life were also endangered in the undesired national groups, as in Poland including in the Warsaw ghetto, by the deprivation of elemental necessities. In winter warm clothing and blankets were requisitioned, firewood and medicine were withheld. The Jews in the Warsaw ghetto were crowded together under conditions of housing inimical to health, and in being denied the use of public parks the Jews were even deprived of the right to fresh air. Such measures were especially pernicious to the health of children and caused the development of various diseases. During the winter of 1940-41, only a single room in a house could be heated in the Warsaw ghetto, and children had to take turns in warming themselves there; after 1941 the Jews in the ghetto received no fuel. ${ }^{19}$

Genocide can involve removal from homes. At first the conditions imposed on Jews in the occupied countries of western Europe were not as severe as those in central and eastern Europe. Shortly after the occupation in the west, however, the German military commanders issued regulations forbidding Jews who had fled from the occupied territory to return their homes. ${ }^{20}$

Lemkin pointed out that acts of the occupier which 'cause humiliations, debilitation by undernourishment, and danger to health' were al ready in violation of the laws of humanity as specified in the preamble to the Hague Regulations. But other acts such as encouraging members of the armed forces to impregnate women nationals of the occupied area by subsidising the costs of the resulting children - were not expressly prohibited by the Hague Regulations and needed now to be seen as coming within the purview of genocide. Lemkin suggested in general terms that the 'German occupant' had embarked upon a gigantic scheme to change, in favour of Germany, the

17. Lemkin 1944: xii, 86-7.

18. Lemkin 1944: 80, 93.

19. Lemkin 1944: 86-8.

20. Lemkin 1944: 75. 
balance of biological forces between it and the captive nations and subjugated peoples for many years to come. Even in the case of German defeat, the Germans would still be in a position to deal with other European nations from the vantage point of numerical, physical, and economic superiority. Lemkin predicted that given the disastrous state of nourishment and health in the occupied countries, the post-war generation of such countries would be stunted, survivors of the ill-fed children of the war years. ${ }^{21}$

Lemkin referred to economic aspects of genocide, where the general aim in the occupied territories was the destruction of the foundations of the economic existence of a national group. Participation in economic life was made dependent upon one's being German or being devoted to the cause of Germanism. There was a comprehensive shifting of wealth to Germans and prohibiting the exercise of trades and occupations by people who were considered unable to promote Germanism. The Jews were immediately deprived of the elemental means of existence. This was contrary to international law at the time. Unless military necessity were involved, the occupier was obliged to restore economic order, which means the right to work and to make a living: 'Depriving the Jews of ... the exercise of professions is a violation of Article 43 of the Hague Regulations.' Lemkin suggested that in relation to the Poles the 'purpose of the occupant' was to shift the economic resources from the Polish national group to the German national group: 'Thus the Polish national group had to be impoverished and the German enriched. ${ }^{22}$

Genocide involves issues of forced labour and free movement. Genocide occurs when an action infringes on the 'liberty' of inhabitants when such action is committed because they belong to a national, religious, or racial group. Lemkin pointed out that depriving the Jews of the right of free movement was a violation of Article 43 of the Hague Regulations. Exposing Jews to mass death by creating unhealthy conditions in the ghettos and in forced labour camps contravened Article 46 of the Hague Regulations; the institution of forced labour was a violation of Article 52. The 'denial of wages to Jews', Lemkin wrote, 'amounts to involuntary servitude, which is a violation of the laws of humanity'. ${ }^{23}$

Genocidal economic measures have more than economic consequences. The lowering of the standard of living creates difficulties in fulfilling what Lemkin referred to as cultural-spiritual requirements. And a daily fight for bread and physical survival may handicap thinking in general and national terms. ${ }^{24}$

As part of a 'synchronised attack on different aspects of life of the captive peoples', genocide has political meanings. In the current world war the Germans were destroying institutions of self-government and imposing a German pattern of administration: 'Every reminder of former national character was obliterated.' Such can apply even to personal and family names. Lemkin noted that nationals of Luxembourg held to have foreign or non-German first names were required to assume corresponding German first names, and if that was not possible they had to select new German first names. German family names could be imposed on Luxembourg nationals. ${ }^{25}$

\footnotetext{
21. Lemkin 1944: xi, 92.

22. Lemkin 1944: $x i i, 77,85$.

23. Lemkin 1944: 77, 93.

24. Lemkin 1944: 85-6.
} 
In its social and legal aspects, genocide entails the disruption of a nation's social cohesion, so vital to its development. The abolition of local law and local courts and the imposition of German law and courts accompanied such destruction of the national social pattern. At the same time there was a Germanisation of the judicial language and of the bar. ${ }^{26}$

There is intellectual and spiritual genocide. Elements of the nation or group such as the intelligentsia and the clergy that provide spiritual leadership are killed or removed. In Poland and Slovenia the intelligentsia and the clergy were in great part separated from the rest of the population and deported for forced labour in Germany. Genocide involves such weakening of the national spiritual resources. ${ }^{27}$

There was genocide in the religious field. In occupied Europe the Germans interfered with the activities of the Church, which in many countries provided not only spiritual but also national leadership. In Luxembourg, eager for children to enroll in pro-N azi youth organisations, the Germans tried to disrupt the role of the Catholic religion in the field of education. In 1939 the Germans burned the great library of the Jewish Theological Seminary at Lublin, Poland. Lemkin quotes from a 1941 German newspaper article celebrating the event. 28

For us it was a matter of special pride to destroy the Talmudic Academy, which was known as the greatest in Poland ... We threw out of the building the great Talmudic library, and carted it to market. There we set fire to the books. The fire last for twenty hours. The Jews of Lublin were assembled around and cried bitterly. Their cries almost silenced us. Then we summoned the military band and the joyful shouts of the soldiers silenced the sound of the Jewish cries.

Frankfurter Zeitung, Wochen-Ausgabe, $28 \mathrm{March} 1941^{29}$

In Poland as well as persecution of the clergy there was systematic pillage and destruction of church property, the German occupying authorities seeking to destroy the religious leadership of the Polish nation. ${ }^{30}$

There was genocide in the field of morality. The German occupiers, Lemkin argues, attempted to create an atmosphere of moral debasement through promoting pornographic publications and motion pictures, and the excessive consumption of alcohol. $^{31}$

Genocide involves questions of the honour of the inhabitants in the occupied territories. Although the Hague Regulations were silent, Lemkin feels, on the 'preservation

\footnotetext{
25. Lemkin 1944: xi, 82-3.

Lemkin 1944: xi, 83.

7emkin 1944: xi, 83, 89.

28. Lemkin 1944: xii, 84-5, 89.

29. Lemkin 1944: 85. In a footnote to $\mathrm{p} 80$ Lemkin mentions the wars of Islam and the Crusades as among classical examples in history of campaigns of extermination in which nations and groups of the population were almost completely destroyed. We can in this connection think of the Crusader invasion of Jerusalem in 1099, when all Muslims within the city walls were slaughtered. When the entire Jewish community gathered within the main synagogueto pray, the Crusaders torched the building and slew anyone who tried to escape. See Amin Malouf 1984: prologue, ii.

30. Lemkin 1944: 89.

31. Lemkin 1944: xii.
} 
of the integrity of a people', the constitutions and the penal codes promulgated after 1918 contained provisions for the protection of the rights of national groups, 'especially of their honour and reputation'. Genocide is constituted in 'humiliations' visited upon a people. ${ }^{32}$ Genocide also involves the destruction of 'family honour'. When Jewish families were separated during deportations, A rticle 46 of the Hague Regulations protecting family honour was violated. ${ }^{33}$

There is cultural genocide. The German occupiers prohibited or destroyed cultural institutions and activities. They substituted vocational education for education in the liberal arts, in order to prevent humanistic thinking, considered dangerous because it was held to promote national thinking. In the incorporated areas the local population was forbidden to use its own language in schools and printing. A rigid control of all cultural activities was introduced. Populations were deprived of inspiration from the existing cultural and artistic values; such occurred especially in Poland, where national monuments were destroyed, and libraries, archives, museums and art works were carried away. ${ }^{34}$

Genocide involves the future honour and diversity of humanity itself. The world represents only so much culture and intellectual vigour as are created by its component national groups (though Lemkin observes that the idea of a nation should not be confused with the idea of nationalism; such would be to mistake the idea of individual liberty with that of egoism). The destruction of any nation therefore results in the loss of its future contributions to the world. Progress in civilisation can be gauged by the respect for and appreciation of the national characteristics and qualities contributed by the different nations to 'world culture' and the 'world community'; and such characteristics and qualities can be offered to humanity by nations weak in defence and poor in economic resources; they are not to be measured in terms of national wealth and power. ${ }^{35}$

\section{IV}

In A xis rule in occupied Europe Lemkin reflected on the relationship of genocide to colonialism. Colonisation was an aspect of political genocide, the replacement by German patterns of administration of formerly self-governing institutions. ${ }^{36}$

The German occupiers of Europe introduced notions of genocide that were the reverse of world-communitarian. The extremely inhuman treatment of Jews (outlined in ch VIII, 'The legal status of the Jews') promoted, Lemkin noted, the 'anti-Christian idea' of the inequality of human beings and of German racial superiority. ${ }^{37}$

Practices of colonialism were important for the German occupiers and constituted the second phase of genocide, the imposition of the national pattern of the oppressor during or after the destruction of the national pattern of the oppressed group: 'This imposition ... may be made upon the oppressed population which is allowed to remain,

\footnotetext{
32. Lemkin 1944: 90-4.

33. Lemkin 1944: 77.

34. Lemkin 1944: xii, 84.

35. Lemkin 1944: 91 and 91 note 51.

36. Lemkin 1944: $x i$.

37. Lemkin 1944: xi.
} 
or upon the territory alone, after removal of the population and the colonization of the area by the oppressor's own nationals. ${ }^{38}$

Colonisation by Germans worked on the theory of Lebensraum, making room for living by Germans in certain areas they conquered. In western Poland, especially, Lemkin observes, colonisation was conducted on a large scale. The Polish population was removed from their homes in order to be replaced by German settlers who were brought in from the Baltic States, the central and eastern districts of Poland, Bessarabia, and from the Reich itself. The properties and homes of the Poles were allocated to German settlers, and to induce them to reside in these areas the settlers received many privileges (including tax exemptions). In Poland special subsidies were provided for German families having 'at least three minor children'. ${ }^{39}$

Those living in a liberal democracy could, Lemkin suggests, choose racial superiority, genocidal aims, and colonisation. Lemkin writes that the German people treated as an entirety must bear responsibility for the history of genocide carried out against the peoples of occupied Europe. Hitler's M ein Kampf had formulated the prolegomenon of destruction and subjugation of other nations: 'The mere fact that the vast majority of the German people put Hitler into power through free elections is evidence that they freely accepted his program which was secret to nobody.' The destruction of Europe, Lemkin feels, would not have been as complete and thorough had the German people not accepted its plan, participated voluntarily in its execution, and (up to the time of writing A xis Rule) profited greatly from it. ${ }^{40}$

Indeed, all groups of the German nation had their share in the spoils of occupied Europe. The German H ausfrau used for her family the food of all occupied countries, Polish geese, Yugoslav pigs, French wine, Danish butter, Greek olives, Norwegian fish; the German industrialist used French and Polish coal, Russian lumber; the German employer in agriculture and industry used for his greater profit imported conscript labor; the German businessman bought up foreign interests and properties, taking advantage of the debasement of non-German currencies; the importer benefited through low prices and compulsory credits; and by Hitler's decree of 28 July 1942, the access to women in occupied countries was facilitated for German manhood by fiat of law. ${ }^{41}$

Lemkin hoped that after the war the United Nations would create 'such political and spiritual conditions that the Germans will be impelled to replace their theory of master race by a theory of a master morality, international law, and true peace' ${ }^{42}$

\section{V}

Lemkin's reflections in Axis rule in occupied Europe on the relationship of genocide to race and colonialism in German-occupied Europe are illuminating for the study of the possible relationship of genocide to settler-colonialism in modern world history. In his impassioned, bitter, mordant 1997 text A little matter of genocide: Holocaust and denial in

\footnotetext{
38. Lemkin 1944: 79.

39. Lemkin 1944: x-xi, 83, 86.

40. Lemkin 1944: xiii.

41. Lemkin 1944: xiv.

42. Lemkin 1944: xiv.
} 
the A mericas 1492 to the present the Native American historian Ward Churchill takes up the challenge to relate Lemkin's definitions and reflections (indeed, the book is dedicated to the memory of Lemkin) to the post-Columbian history of the Americas. Churchill's book is also a contribution to the comparative study of European settlercolonies.

Churchill expresses anger at how the range, subtlety and inclusiveness of Lemkin's 1944 definitions have been diluted, reduced, and distorted since World War II. The process, he argues, began with the 1948 UN convention. In specifying five different categories of actions (which have the intent to destroy, in whole or in part, a national, ethnic, racial or religious group), the Convention follows Lemkin. ${ }^{43}$ Because of objections from some UN members, however, in particular the United States, all that remained of cultural genocide from Lemkin's original definition was a provision prohibiting the forced transfer of children. The effect of the truncation of the notion of 'cultural genocide' was that the UN convention came to place far more weight on direct killing than had ever been in Lemkin's wide-ranging formulations, his composite of different forms. ${ }^{44}$

Lemkin's concept of genocide, Churchill reminds us, does not assume a hierarchy of actions and certainly was never meant to pertain exclusively to direct killing, this being but one means to the end of destroying the identity of a targeted group. He protests at the way a simplistic reductive reading of Lemkin has become orthodoxy in international law, academic and scholarly discussion, and popular understanding. ${ }^{45}$ In his view, the UN convention also created severe problems for the comprehension, condemnation and possible punishment of the crime of genocide by inserting the term 'intent' into its definition. Introducing the notion of demonstrable intent, he suggests, established a requirement that would be virtually impossible ever to prove. ${ }^{46}$

For Churchill, the greatest series of genocides ever perpetrated in history - in terms of magnitude and duration - occurred in the Americas, led by Columbus himself when, having with the blessing of the Spanish Crown installed himself as viceroy and governor of the Caribbean islands and America, he took up residence in 1493 in Española (today Haiti and the Dominican Republic). By first dispossessing them of their abundant cultivated fields and then instituting policies of slavery and systematic extermination, Columbus reduced the formerly prosperous Taino people from as many as eight million at the outset of his regime to about three million in 1496. By the time of Columbus' departure in 1500, only 100000 Taino had survived; by 1514, there were 22 000; by 1542, only two hundred were recorded. The pattern of destruction inaugurated by Columbus continued as the pattern of genocide for the Americas, so that, Churchill suggests, it is probable that more than one hundred million pre-Columbian peoples died in the course of Europe's ongoing conquest of the continent. A hemispheric population estimated to have been as great as 125 million was reduced by something over 90 per cent. From the outset entire civilisations were eradicated. ${ }^{47}$

\footnotetext{
43. Churchill 1997: 71.

44. Churchill 1997: 367-8, 408, 412.

45. Churchill 1997: 70; see also : 368, 388, 399-418, 420, 423, 433.

46. Churchill 1997: 412, 418.

47. Churchill 1997: 1, 85-7, 97, 129, 403. See also Stannard 1992.
} 
Many died from disease and starvation. Such means of death, loss, and sometimes extinction was and still is, Churchill argues, the responsibility of the European invaders and settlers. He observes that a considerable portion of those who died in the $\mathrm{Nazi}$ death camps as well as in forced marches died from starvation as well as epidemics of diseases like dysentery and typhus. Yet the Nazis were nonetheless found culpable under international law after the war for such deaths by deliberately imposing the conditions which led to the spread of starvation and sickness among them. Churchill reminds his readers that the English Puritans rejoiced that diseases like small pox were having a catastrophic effect - they could daily observe the death and terror - on Indian numbers, thus facilitating rapid colonisation. Some of the worst examples of escalating death by sickness and disease occurred on the Spanish Christian missions in Florida, Texas, California, Arizona, and $\mathrm{N}$ ew Mexico in the period 1690-1845. After the military delivered captive Indians to the missions, they were expected to perform arduous agricultural labour while being provided with no more than 1400 calories per day in low-nutrient foods, with some missions supplying as little as 715 calories per day. A mongst the survivors, stress, anxiety, trauma, depression, demoralisation and despair led not only to vulnerability to physical and psychological illnesses but also to a plummeting of birth rates. In his own definition of genocide that he offers at the end of his book, Churchill in the spirit of Lemkin's 1944 discussion suggests that the crime of genocide should include not only forms of systematic economic deprivation leading to starvation and other deterioration in the physical well being of group members but also denial of fundamental medical attention to a group. ${ }^{48}$

In Churchill's view, the English distinguished themselves in the range and extent of their genocidal actions in North America: 'The most overtly genocidal of the European powers operating in $\mathrm{N}$ orth America was England.' From almost the first moment of invasion in the 1580s, the English established processes of dislocating the lives of indigenous peoples and destroying the economic basis of their survival, processes that escalated in the following two hundred years. The English like the Spanish before them in the Americas engaged in systematic direct killing of the most 'savage' kind, including mounting of the skulls of dead Indians on poles. By the late 1600s, the Pamunkeys, Chickahominies, Naunsemonds, Rappahannocks, Paspaheghs and other smaller peoples were reduced to a remnant of no more than 600 people, rendered destitute, homeless, starving, disease-ridden, harried, and harassed. Meanwhile the English, having destroyed a once-thriving civilisation, now established themselves and their economy and society on its ruins. Churchill remarks that the goal of the English settlement everywhere in North A merica was to create 'Indian-free zones of occupation for itself, as rapidly as practicable, in every locality to which it lay claim' ${ }^{49}$

European settler-colonial practices since 1492 were, Churchill suggests, influential in $\mathrm{N}$ azi conceptions of colonisation, serving as models to be followed. Churchill compares Columbus' policies and practices of settlement of the Americas and racial ideas during his reign as governor on Española to Heinrich Himmler and Nazi notions of Untermenschen. The Spanish policy of conscripting entire indigenous populations into forced labour served as a prototype for Nazi policies in Eastern Europe. United States'

48. Churchill 1997: 86, 139-44, 151, 432-3.

49. Churchill 1997: 147-8, 166-67, 180, 199-202. 
clearing operations, so-called, against the indigenous peoples of North America also served as an exemplar for $\mathrm{N}$ azi notions and practices of Lebensraum. Settler-colonies like 'Australia, N ew Zealand, South Africa, A rgentina, the United States, and Canada' led the way in setting out to achieve what the Nazis also set out to achieve, the displacement of indigenous populations and their replacement by incoming peoples held to be racially superior. ${ }^{50}$

Churchill argues that settler-colonies around the world established during European expansion post-1492 in the United States, Canada, Australia, N ew Zealand, South Africa, and Argentina, are not only potentially but inherently genocidal. In settler-colonies - again Churchill is reprising Lemkin's definition of genocide as a twofold process of dispossession of the life-world of a national group and imposition of the life pattern of another - 'an invading group quite literally supplants the indigenous population on its own landbase'. A settler-colony to be a settler-colony requires 'wholesale displacement, reduction in numbers, and forced assimilation of native peoples'. Churchill feels that Sartre, addressing the war crimes tribunal established by Bertrand Russell in 1967 (prompted by US destructive acts in the Vietnam War), went a long way towards restoring Lemkin's original notions of genocide by equating colonialism and genocide. In Churchill's view, settler-colonies involve genocide in their very being. ${ }^{51}$

\section{V}

In the last decade or so historians have been exploring concepts like genocide, Holocaust, trauma, and memory. Notable here is Peter N ovick's challenging The H ol ocaust in A merican life (1999) and a renewed interest in the writings of thinkers like Raphaë Lemkin and Hannah Arendt. ${ }^{52}$ Our contributors discuss a wide range of texts, from American, German, and other scholars. Specialists in Australian history have only recently begun participating in these broad international debates. We see the essays in this issue of Aboriginal $\mathrm{H}$ istory as valuable contributions to this ongoing global conversation.

\section{References}

Churchill, Ward 1997, A little matter of genocide: Holocaust and denial in the A mericas 1492 to the present, City Lights Books, San Francisco.

Clendinnen, Inga 2001, 'First contact', The A ustralian's Review of Books: 6-7 (May), 26.

Connelly, John 1999, 'Nazis and Slavs: from racial theory to racist practice', Central European $\mathrm{H}$ istory 32(1): 1-33.

50. Churchill 1997: 52, 84-8. Cf. Connelly 1999: 29, who writes that the $N$ azis wished to emulate the English success in colonisation, including the management of sometimes hugenumbers of subject peoples: 'Hitler ... referred to the future regime in Eastern Europe as approximating that of the English in India'. Cf. also Finkelstein 2000: 145 - 'Hitler modelled his conquest of the East on the American conquest of the West'.

51. Churchill 1997: 84, 415-6, 421-2, 441 note 64. Sartre's address was published as 'On Genocide' in R amparts February 1968; an expanded version appeared as a 1968 book, On genocide and a summary of the evidence and judgments of the International $W$ ar Crimes Tribunal, Beacon Press, Boston.

52. N ovick 1999. See also Curthoys, N ed 2000/ 1, which discusses N ovick and Ward Churchill as well as A rendt's writings. 
Curthoys, Ned 2000/ 1 'The politics of Holocaust representation: the worldly typologies of Hannah Arendt', A rena Journal New Series no.16: 49-74.

Docker, John 2001, 1492: the poetics of diaspora, Continuum, London.

Evans, Raymond and Bill Thorpe 2001, 'The massacre of A boriginal history', O verland 163, winter: 21-39.

Finkelstein, N orman G 2000, The H olocaust industry: reflections on the exploitation of Jewish suffering, Verso, London.

Gaita, Raimond 2001, "Why the impatience? Genocide, "ideology", and practical reconciliation', A ustralian Book Review, July: 25-31.

Green, N eville 1995, The Forrest River massacres Fremantle Arts Centre Press, Fremantle.

Lemkin, Raphaël 1944, A xis Rule in O ccupied Europe: Laws of O ccupation, A nalysis of G overnment, Proposals for Redress Columbia University Press, New York.

Malouf, A min 1984, The Crusades through A rab eyes, trans. Jon Rothschild, AI Saqi Books, London.

Moran, Rod c1999, M assacre myth: an investigation into allegations concerning the mass murder of A borigines at Forrest River 1926, Access Press, Bassendean, WA.

Moses, Dirk 2000, 'An antipodean genocide: the origins of the genocidal moment in the colonization of Australia', J ournal of G enocide Research 2(1): 89-106.

Neumann, Klaus 1998, 'Remembering victims and perpetrators', U TS Review 4(1), May: 1-17.

Novick, Peter 1999, The H olocaust in A merican life Houghton Mifflin, Boston.

Reynolds, Henry 2001, An indelible stain? The question of genocide in A ustralia's history, Viking, Ringwood.

Schaffer, Kay 2001, 'Manne's generation: White nation responses to the Stolen Generation report', A ustralian H umanities R eview, June, http:/ / www.latrobe.edu.au/ AHR/ archive/ Issue-June-2001/ schaffer.html.

Stannard, David E 1992, A merican H olocaust: the conquest of the N ew W orld Oxford University Press, $\mathrm{N}$ ew York.

Windschuttle, Keith 2001, 'When history falls victim to politics', TheA ge 14 July. 